\title{
Extracellular nucleotides inhibit growth of human oesophageal cancer cells via $\mathrm{P}_{2} \mathrm{Y}_{2}$-receptors
}

\author{
K Maaser ${ }^{1,2}$, M Höpfner',2, H Kap', AP Sutter', B Barthel', B von Lampe', M Zeitz' and H Scherübl*,' \\ 'Medical Clinic I, Gastroenterology/Infectious Diseases/Rheumatology, Benjamin Franklin Clinics, Free University of Berlin, Hindenburgdamm 30, 12200 Berlin, \\ Germany
}

Extracellular ATP is known to inhibit growth of various tumours by activating specific purinergic receptors (P2-receptors). Since the therapy of advanced oesophageal cancer is unsatisfying, new therapeutic approaches are mandatory. Here, we investigated the functional expression and potential antiproliferative effects of P2-purinergic receptors in human oesophageal cancer cells. Prolonged incubation of primary cell cultures of human oesophageal cancers as well as of the squamous oesophageal cancer cell line Kyse-140 with ATP or its stable analogue ATP $\gamma$ S dose-dependently inhibited cell proliferation. This was due to both an induction of apoptosis and cell cycle arrest. The expression of P2-receptors was examined by RT$\mathrm{PCR}$, immunocytochemistry, and $\left[\mathrm{Ca}^{2+}\right]_{i}$-imaging. Application of various extracellular nucleotides dose-dependently increased $\left[\mathrm{Ca}^{2+}\right]_{\text {i. }}$ The rank order of potency was ATP=UTP $>$ ATP $\gamma S>$ ADP $=$ UDP. 2 -methylthio-ATP and $\alpha, \beta$-methylene-ATP had no effects on $\left[\mathrm{Ca}^{2+}\right]_{\text {i }}$. Complete cross-desensitization between ATP and UTP was observed. Moreover, the phospholipase C inhibitor U73122 dose-dependently reduced the ATP triggered $\left[\mathrm{Ca}^{2+}\right]_{i}$ signal. The pharmacological features strongly suggest the functional expression of G-protein coupled $\mathrm{P}_{2} \mathrm{Y}_{2}$-receptors in oesophageal squamous cancer cells. $\mathrm{P}_{2} \mathrm{Y}_{2}$-receptors are involved in the antiproliferative actions of extracellular nucleotides. Thus, $\mathrm{P}_{2} \mathrm{Y}_{2}$-receptors are promising target proteins for innovative approaches in oesophageal cancer therapy.

British Journal of Cancer (2002) 86, 636-644. DOl: I0.1038/sj/bjc/6600 I00 www.bjcancer.com

(c) 2002 Cancer Research UK

Keywords: cancer; proliferation; apoptosis; purinergic receptor; calcium signalling

ATP and related compounds are widespread transmitters for extracellular communication in many cell types. By coupling to specific purinergic receptors ATP is involved in a large variety of cellular functions (Ralevic and Burnstock, 1998). The classification of P2 purinergic receptors, first suggested by Burnstock in the late seventies (Burnstock, 1978) distinguished between two major classes of $\mathrm{P} 2$-purinoceptors, first ionotropic P2-receptors (P2X), which are ligand-gated receptors containing an intrinsic ion channel, and second metabotropic P2-receptors (P2Y), which belong to the superfamily of G-protein coupled receptors. This classification has recently been expanded (Barnard et al, 1994; Fredholm et al, 1997) to accommodate the results of cloning studies which revealed the existence of multiple subclasses of P2Y purinoceptors. While ionotropic P2X-receptors are mainly expressed in the nervous system, platelets and in smooth muscle cells, metabotropic P2Yreceptors are distributed in a large variety of tissues, including epithelial tissues of the gastrointestinal system (Dubyak and elMoatassim, 1993; Roman and Fitz, 1999). P2Y-receptors mainly couple to $\mathrm{G}_{\mathrm{q} / 11}$-proteins to activate phospholipase C. Upon activation phosphatidylinositolbisphosphate $\left(\mathrm{PIP}_{2}\right)$ is hydrolyzed leading to the generation of $\mathrm{IP}_{3}$ (inositoltrisphosphate), which triggers calcium release from intracellular stores (SR/ER) (Lytton et al, 1991). Depletion of intracellular calcium stores in turn induces

*Correspondence: H Scherübl, MD, PhD; E-mail: hscher@zedat.fu-berlin.de ${ }^{2} \mathrm{~K}$ Maaser and $\mathrm{M}$ Höpfner contributed equally to this work

Received 26 March 200I; revised 12 September 200I; accepted 23 November 2001 calcium influx across the plasma membrane (Lytton et al, 1991). This $\mathrm{Ca}^{2+}$-influx mechanism, which depends on an initial elevation of $\left[\mathrm{Ca}^{2+}\right]_{\mathrm{i}}$, has been referred to as 'calcium release' activated calcium influx' or 'capacitative calcium entry' (Berridge, 1995).

ATP is known to inhibit cancer growth in various tumour models (Rapaport, 1990; Haskell et al, 1996; Correale et al, 1997; Ishikawa et al, 1997). ATP-induced apoptosis was in the past considered to be mediated by ionotropic P2-receptors only (Fredholm et al, 1994; Bronte et al, 1996; Correale et al, 1997). However, there is growing evidence that by altering intracellular calcium concentrations metabotropic P2-receptors may be involved in both growth inhibition and programmed cell death (Fang et al, 1992; Duncan et al, 1996; McConkey and Orrenius, 1997; Höpfner et al, 2001).

Oesophageal cancers have not been studied in this respect so far. Therefore we investigated the P2-receptor-mediated, cell cycle arresting and apoptosis inducing effects of extracellular nucleotides in oesophageal cancer cells.

\section{MATERIALS AND METHODS}

\section{Materials}

Fura-2/AM, gramicidin, ATP, ATP $\gamma \mathrm{S}$, UTP, ADP, UDP, 2methylthio-ATP (2MeSATP), $\alpha, \beta$-methylene-ATP $(\alpha, \beta$-meATP $)$ and adenosine were purchased from Sigma Chemicals Co. (München, Germany). SBFI/AM and pluronic-F127 were purchased from Molecular Probes (Eugene OR, USA). RPMI 1640 was obtained from Biochrom-Seromed KG (Berlin, Germany). All stock solu- 
tions except from fura-2/AM, SBFI/AM and adenosine (solubilized in DMSO) were prepared in water and stored in aliquots of appropriate size at $-20^{\circ} \mathrm{C}$ until use.

\section{Cell culture}

The human oesophageal squamous carcinoma cell line Kyse-140 (Shimada et al, 1992) was maintained in standard RPMI 1640 medium, complemented with $10 \%$ foetal calf serum and was kept in an incubator $\left(37^{\circ} \mathrm{C}, 5 \% \mathrm{CO}_{2}\right.$ humidified atmosphere).

Primary cell cultures of histologically verified oesophageal squamous cell carcinomas were established from endoscopic biopsies of seven oesophageal cancer patients (three female, four male patients, age: 52-69 years). The human tumour material was used according to the standards set by the Ethical Committee of the Benjamin Franklin University Hospital, Free University of Berlin, Germany. Preparation was performed by mechanical dissection using an automated disaggregation system (Medimachine; Becton Dickinson, Heidelberg, Germany) as described elsewhere in detail (Maaser et al, 2001). The isolated human oesophageal carcinoma cells were maintained in nutrient medium based on Earle's 199medium (Biochrom, Berlin, Germany) complemented with $20 \%$ foetal calf serum, $2 \mathrm{mM}$ L-glutamine, $2 \%(\mathrm{v} / \mathrm{v})$ Biotect protectivemedium (Biochrom, Berlin, Germany), penicillin $\left(100 \mathrm{U} \mathrm{ml}^{-1}\right)$, streptomycin $\left(100 \mu \mathrm{g} \mathrm{ml}^{-1}\right)$, amphotericin B $(1 \% \mathrm{v} / \mathrm{v})$ and were kept in an incubator $\left(37^{\circ} \mathrm{C}, 5 \% \mathrm{CO}_{2}\right.$ humidified atmosphere). Half of the medium was changed every second day. Cells remained in culture for at least 2 days before the experiments were carried out. Squamous epithelial origin of the isolated primary culture cells was confirmed by immunostaining with a FITC-labelled cytokeratin antibody (cytokeratin/FITC clone MNF 116, DAKO, Hamburg, Germany).

\section{Cell proliferation assay}

Antiproliferative effects of a sustained application of P2-receptor agonists on human oesophageal carcinoma cells were studied by performing proliferation assays according to the crystal violet method (Gillies et al, 1986). In brief, Kyse-140 cells were seeded on 96-well plates at a density of 5000 cells per well. ATP, ATP $\gamma$ S, $2 \mathrm{MeSATP}$ or adenosine were added in concentrations from 100 to $500 \mu \mathrm{M}$. If stated, cells were additionally treated with 10 or $100 \mu \mathrm{M}$ of the ecto-ATPase inhibitor ARL 67156 (6-N,Ndiethyl- $\beta$ - $\gamma$-dibromomethylene-D-adenosine- $5^{\prime}$-triphosphate trisodium; RBI, Natick, MA, USA) which was given $1 \mathrm{~h}$ before as well as during nucleotide incubation. Each concentration group consisted of 10 wells. The incubation medium was changed daily. Cells of each well were washed with phosphate-buffered saline (PBS) and fixed with $100 \mu$ l glutaraldehyde (1\% v/v) in PBS for $15 \mathrm{~min}$ at room temperature. After another washing step cells were stained with $0.1 \%$ crystal violet in PBS for $30 \mathrm{~min}$ at room temperature. The unbound dye was removed by washing with $\mathrm{H}_{2} \mathrm{O}$ for $30 \mathrm{~min}$. Crystal violet which had absorbed onto the cells was solubilized with $100 \mu \mathrm{l}$ Triton X-100 (0.2\%) in PBS for at least $24 \mathrm{~h}$ at $37^{\circ} \mathrm{C}$. The crystal violet coloured solution was spectrophotometrically measured at $570 \mathrm{~nm}$ using an ELISA-Reader. In the range between 500 to 100000 cells per well the measured extinction was linear to the number of cells.

\section{Cell cycle analysis}

Cell cycle analysis was performed by using the method of Vindelov and Christensen (1990). $5 \times 10^{5}$ cells per well were cultured for $24 \mathrm{~h}$ and then exposed to the respective nucleotide for another $24 \mathrm{~h}$. Cells were trypsinized, washed, and the nuclei were isolated using CycleTest PLUS DNA Reagent Kit (Becton Dickinson, Heidelberg, Germany). DNA was stained with propidium iodide according to the manufacturers' instructions. The DNA content of the nuclei was detected by flow cytometry and analyzed using CellFit software (Becton Dickinson, Heidelberg, Germany).

\section{Caspase-3 activity assay}

Cells were incubated with medium containing ATP or ATP $\gamma S$ at concentrations from 50 to $500 \mu \mathrm{M}$ for $48 \mathrm{~h}$, washed twice with $\mathrm{PBS}$, and stored at $-80^{\circ} \mathrm{C}$ until use. Approximately $10^{6}$ cells were lysed with $500 \mu \mathrm{l}$ lysis buffer ( $10 \mathrm{~mm}$ Tris- $\mathrm{HCl}, 10 \mathrm{~mm} \mathrm{NaH} \mathrm{PO}_{4} /$ $\mathrm{Na}_{2} \mathrm{HPO}_{4}, 130 \mathrm{~mm} \mathrm{NaCl}, 1 \%$ Triton X-100, $10 \mathrm{~mm} \mathrm{NaPP}$, pH 7.5) and total protein content was quantified using the BCA protein assay kit (Pierce, Rockford, IL, USA). Caspase-3 activity was calculated from the cleavage of the fluorogenic substrate DEVD-AMC (Nicholson et al, 1995). In brief, $100 \mu \mathrm{l}$ cell lysate containing $500 \mu \mathrm{g} \mathrm{ml}^{-1}$ protein was incubated with $100 \mu \mathrm{l}$ substrate solution ( $2 \mu \mathrm{g}$ caspase- 3 substrate AC-DEVD-AMC, $20 \mathrm{mM}$ HEPES, $10 \%$ glycerol, $2 \mathrm{~mm}$ DTT, $\mathrm{pH} 7.5)$ for $1 \mathrm{~h}$ at $37^{\circ} \mathrm{C}$. Cleavage of DEVD-AMC was measured with a VersaFluor fluorometer (Biorad, Munich, Germany) using a $360 \mathrm{~nm}$ excitation and a $460 \mathrm{~nm}$ emission wavelength.

\section{TUNEL assay}

Determination of apoptosis specific DNA strand breaks was performed by terminal deoxynucleotidyl transferase-mediated dUTP nick-end labelling (TUNEL) assay (Li et al, 1996) according to the manufacturers' instructions (Roche, Mannheim, Germany). Cells were fixed with $4 \%$ paraformaldehyde for $1 \mathrm{~h}$ at room temperature, washed once with $200 \mu \mathrm{l} 1 \%$ BSA in PBS, followed by permeabilization with $0.1 \%$ Triton X-100 in $0.1 \%$ sodium citrate solution for $2 \mathrm{~min}$ on ice. After washing with $200 \mu \mathrm{l} 1 \%$ BSA in PBS, cells were stained with $50 \mu \mathrm{l}$ TUNEL reaction mixture (Roche, Mannheim, Germany) for $1 \mathrm{~h}$ at $37^{\circ} \mathrm{C}$ in a humidified atmosphere in the dark. After two additional washing steps, nuclear fluorescence was analyzed using a Zeiss Axioskop-2 microscope.

\section{Reverse transcriptase chain reaction (RT - PCR)}

RNA isolation, reverse transcription and PCR reactions were carried out as described elsewhere in detail (Glassmeier et al, 1998). Total RNA was isolated from cells using the RNeasy Kit (Qiagen, Valencia, CA, USA) according to the manufacturers' instructions. To eliminate any possible contamination with genomic DNA, RNAs were treated with $1 \mathrm{U}$ DNAse I (Gibco, Karlsruhe, Germany) per $\mu \mathrm{g}$ RNA for $15 \mathrm{~min}$ at room temperature. Furthermore, possible contamination with genomic DNA was excluded by control experiments omitting the reverse transcriptase. Purified RNA was reverse transcribed into cDNA using the oligo-dT-primers and the SuperScript Preamplification-Kit (Gibco, Karlsruhe, Germany). PCR reactions were carried out in a total volume of $50 \mu \mathrm{l}$ containing $400 \mathrm{nM}$ of each primer, $200 \mu \mathrm{M}$ of each dNTP (Pharmacia, Uppsala, Sweden), $50 \mathrm{mM} \mathrm{KCl}, 1.5 \mathrm{mM} \mathrm{MgCl}, 10 \mathrm{mM}$ Tris, and 1 Unit Taq-polymerase (Pharmacia, Uppsala, Sweden). PCR was performed in a Peltier-thermocycler (PTC-200, MJ-Research, USA) at the following conditions: Initial heating to $95^{\circ} \mathrm{C}$ for $5 \mathrm{~min}$, then 30 cycles at $95^{\circ} \mathrm{C}$ for $30 \mathrm{~s}, 60^{\circ} \mathrm{C}$ for $30 \mathrm{~s}$ for $\mathrm{P} 2 \mathrm{X}$ - and $\mathrm{P} 2 \mathrm{Y}_{6}$-primers, or $70^{\circ} \mathrm{C}$ for $30 \mathrm{~s}$ for $\mathrm{P}_{2} \mathrm{Y}_{1,2,4}$-primers, or $63^{\circ} \mathrm{C}$ for $1 \mathrm{~min}$ for $\beta$-actin primers, respectively, and $72^{\circ} \mathrm{C}$ for $1 \mathrm{~min}$, followed by a final elongation step of $7 \mathrm{~min}$ at $72^{\circ} \mathrm{C}$. Amplification of the cDNA sequences encoding for the tested human P2-receptor subtypes was performed using specific and established primer sequences (Schöfl et al, 1999; Yamamoto et al, 2000; Höpfner et al, 2001) as shown in Table 1. The specificity of the cDNA products was additionally controlled by direct sequencing which was performed by Invitek Sequencing Service $\mathrm{GmbH}$, Berlin-Buch, Germany. As a control for the amount of cDNA, RT-PCR was performed using $\beta$-actin primers (Table 1). 
Table I Primers used to identify human P2-receptor subtypes

\begin{tabular}{|c|c|c|}
\hline $\begin{array}{l}\text { P2-receptor } \\
\text { subtype }\end{array}$ & Sequences of primer pairs & $\begin{array}{l}\text { PCR-product } \\
\text { size (bp) }\end{array}$ \\
\hline $\mathrm{P} 2 \mathrm{X}_{1}$ & $\begin{array}{l}\text { forward: 5'-AGTCTTCCAGCTTGGCTACG-3' } \\
\text { reverse: 5'-TCCTCATGTTCTCCTGCAGG-3' }\end{array}$ & 509 \\
\hline $\mathrm{P} 2 \mathrm{X}_{3}$ & $\begin{array}{l}\text { forward: 5'-TGCATATCCGACTTCTTCACC-3' } \\
\text { reverse: 5'-CTCAGCTTCCATCATGATGG-3' }\end{array}$ & 501 \\
\hline $\mathrm{P} 2 \mathrm{X}_{4}$ & $\begin{array}{l}\text { forward: 5'-AACTGCTCATCCTGGCCTAC-3' } \\
\text { reverse: 5'-ACGTGTGTGTCATCCTCCAC-3' }\end{array}$ & 412 \\
\hline $\mathrm{P} 2 \mathrm{X}_{5}$ & $\begin{array}{l}\text { forward: 5'-CAATGTGATGGACGTCAAGG-3' } \\
\text { reverse: 5'-TGTGAGCTGCTCAGATAGCC-3' }\end{array}$ & 517 \\
\hline $\mathrm{P} 2 \mathrm{X}_{7}$ & $\begin{array}{l}\text { forward: 5'-AAGGAATTCAGACCGGAAGG-3' } \\
\text { reverse: 5'-TTGAGCCGATGTACACAACC-3' }\end{array}$ & 585 \\
\hline$P 2 Y_{1}$ & $\begin{array}{l}\text { forward: 5'-TGTGGTGTACCCCCTCAAGTCCC-3' } \\
\text { reverse: 5'-ATCCGTAACAGCCCAGAATCAGCA-3' }\end{array}$ & 260 \\
\hline $\mathrm{P}_{2} \mathrm{Y}_{2}$ & $\begin{array}{l}\text { forward: 5'-CCAGGCCCCCGTGCTCTACTTTG-3' } \\
\text { reverse: 5'-CATGTTGATGGCGTTGAGGGTGTG-3' }\end{array}$ & 367 \\
\hline $\mathrm{P} \mathrm{Y}_{4}$ & $\begin{array}{l}\text { forward: 5'-CGTCTTCTCGCCTCCGCTCTCT-3' } \\
\text { reverse: 5'-GCCCTGCACTCATCCCCTTTTCT-3' }\end{array}$ & 432 \\
\hline $\mathrm{P} \mathrm{Y}_{6}$ & $\begin{array}{l}\text { forward: 5'-CCGCTGAACATCTGTGTC-3' } \\
\text { reverse: 5'-AGAGCCATGCCATAGGGC-3' }\end{array}$ & 464 \\
\hline$\beta$-actin & $\begin{array}{l}\text { forward: 5'-TTCCTGGGCATGGAGTCCTGTGG-3' } \\
\text { reverse: 5'-CGCCTAGAAGCATTTGCGGTGG-3' }\end{array}$ & 336 \\
\hline
\end{tabular}

\section{Immunofluorescence labelling and fluorescence microscopy}

Cells were washed with PBS, fixed by incubation with $4 \%$ paraformaldehyde in PBS for $30 \mathrm{~min}$ at room temperature, and washed again with PBS. Cells were then incubated for $3 \mathrm{~h}$ at room temperature with $5 \mu \mathrm{g} \mathrm{ml}^{-1}$ polyclonal rabbit-anti-human $\mathrm{P}_{2} \mathrm{Y}_{2}$ antibody, which was kindly provided by Dr BK Kishore (Kishore et al, 2000), or with $5 \mu \mathrm{g} \mathrm{ml}^{-1}$ polyclonal rabbit-anti-human $\mathrm{P}_{2} \mathrm{Y}_{4}$ antibody Ab-1 (Oncogene, Cambridge, CA, USA). Thereafter cells were washed twice with PBS and incubated with $4 \mu \mathrm{g} \mathrm{ml}^{-1}$ secondary Alexa ${ }^{\mathrm{TM}}$ 488-labelled goat-anti-rabbit IgG antibody (Molecular Probes, Eugene, OR, USA) for $1 \mathrm{~h}$ at room temperature. Fluorescence and transmission images were obtained using a Zeiss Axioskop-2 microscope.

\section{Measurement of intracellular calcium and sodium}

Kyse-140 cells were grown on $25 \mathrm{~mm}$ glass coverslips coated with poly- $L$-lysine for improved attachment. For measurement of intracellular calcium cells were loaded with the fluorescent dye fura-2/ $\mathrm{AM}(5 \mu \mathrm{M})$ for $45 \mathrm{~min}$ at room temperature in a bath solution containing: $130 \mathrm{mM} \mathrm{NaCl}, 5.4 \mathrm{mM} \mathrm{KCl}, 1 \mathrm{mM} \mathrm{CaCl}_{2}, 1 \mathrm{mM} \mathrm{MgCl}_{2}$, $10 \mathrm{~mm}$ glucose and $10 \mathrm{mM}$ HEPES, adjusted to $\mathrm{pH} 7.3$ with $\mathrm{NaOH}$. The constituents of $\mathrm{Ca}^{2+}$-free solutions were the same as the bathing solution described above except that $\mathrm{CaCl}_{2}$ was omitted and $0.1 \mathrm{mM}$ EGTA was added to eliminate possible $\mathrm{Ca}^{2+}$-contaminations of the other constituents. Fluorescence measurements were performed at room temperature with a digital imaging system of T.I.L.L. Photonics (München, Germany) (Glassmeier et al, 1998; Höpfner et al, 1998). Fura-2 fluorescence was excited alternatively at 340 and $380 \mathrm{~nm}$ with a monochromator provided by a $75 \mathrm{~W}$ xenon lamp. Cellular fluorescence was filtered through a $510 \mathrm{~nm}$ band pass filter. Images were digitalized and analyzed by FUCAL $5.12 \mathrm{c}$ software of T.I.L.L. Photonics. Ratio images were generated either at 1.5 or $2 \mathrm{~s}$ intervals. To compensate for background noise illumination of a cell-free area was subtracted. The calculation of the fura-2 signal was done as described in detail elsewhere (Morgan and Thomas, 1999). To calculate $\left[\mathrm{Ca}^{2+}\right]_{\mathrm{i}}$ the equation of Grynkiewicz et al (1985) was used. The data are mainly represented as changes in $340 / 380 \mathrm{~nm}(\Delta \mathrm{F} 340 / \mathrm{F} 380 \mathrm{~nm})$ fluorescence ratio, which is proportional to $\left[\mathrm{Ca}^{2+}\right]_{\mathrm{i}}$. Unless representative single tracings are shown, the results are given as means \pm s.e.m.

Changes in intracellular sodium concentration were monitored by loading the cells with the fluorescent dye SBFI/AM $(10 \mu \mathrm{M})$ for $2 \mathrm{~h}$ at $37^{\circ} \mathrm{C}, 5 \% \mathrm{CO}_{2}$ humidified atmosphere in the same bath solution as described above. For better dispersion of the dye in the loading medium the nonionic and nondenaturing detergent pluronic F-127 $(0.04 \%(\mathrm{w} / \mathrm{v}))$ was added. To remove extracellular remainders of SBFI/AM, the cells were washed three times in bath solution. Then the samples were kept in bath solution for at least $20 \mathrm{~min}$ to ensure complete intracellular de-esterafication of the dye. Fluorescence recordings with SBFI-loaded cells were performed under the same conditions as described above for fura-2, except from the excitation wavelength of the $\mathrm{Na}^{+}$-bound dye which was $344 \mathrm{~nm}$. The data are represented as changes in $344 / 380 \mathrm{~nm}(\Delta \mathrm{F} 344 / \mathrm{F} 380 \mathrm{~nm})$ fluorescence ratio, which is proportional to $\left[\mathrm{Na}^{+}\right]_{\mathrm{i}}$.

\section{Statistical analysis}

Comparison of multiple means was performed with nonparametric ANOVA. Comparison of individual drug treatments to control treatments was performed using an unpaired, two-tailed MannWhitney $U$-test for proliferation and caspase-3 activity experiments. Data are expressed as mean percentage of control \pm s.e.m. For cell cycle analysis the unpaired student $t$-test was used. $P$ values were considered to be significant at $<0.05$.

\section{RESULTS}

\section{Growth inhibitory effects of extracellular nucleotides on oesophageal cancer cells}

ATP is known to inhibit cancer growth in various tumour models (Agteresch et al, 1999). However, its role in growth control of human oesophageal cancer remains elusive. To investigate putative growth modulating effects of extracellular nucleotides in oesophageal carcinoma cells, cell proliferation assays were performed with Kyse-140 cells. For these experiments ATP, the hydrolysis resistant 
ATP derivative ATP $\gamma \mathrm{S}$, adenosine, and 2MeSATP were used (Figure 1A). Both ATP and ATP $\gamma$ S dose-dependently decreased cellular proliferation. The poorly hydrolysable ATP $\gamma \mathrm{S}$ was even more effective $\left(\mathrm{IC}_{50}=234 \pm 51 \mu \mathrm{M}\right.$ after $72 \mathrm{~h}$ of incubation) than ATP $\left(\mathrm{IC}_{50}=450 \pm 31 \mu \mathrm{M}\right)$. In contrast, $2 \mathrm{MeSATP}$ failed to inhibit the growth of Kyse-140 cells even at a concentration of $500 \mu \mathrm{M}$. Adenosine, the major breakdown product of ATP, showed no effects on cellular proliferation up to $250 \mu \mathrm{M}$. Only at the high adenosine concentration of $500 \mu \mathrm{M}$, mimicking the unlikely complete degradation of the maximal ATP-dose of $500 \mu \mathrm{M}$ to adenosine, a growth inhibitory effect by adenosine of $24 \pm 6 \%$ was observed, presumably mediated by an activation of adenosine specific P1-receptors, which are ubiquitously expressed (Fang et al, 1992; Vandewalle et al, 1994). However, the adenosine-evoked effect is about $50 \%$ less than those of ATP at the same concentration of ATP $(52 \pm 6 \%)$. This means that even in case of a complete hydrolysis of ATP to adenosine, the antiproliferative effects of an ATP treatment can only be partially explained by an involvement of adenosine-mediated effects.

Ecto-ATPases are membrane bound enzymes which dephosphorylate ATP, thereby terminating the stimulatory effects of ATP on P2-receptors. It has been shown by others that in several tissues the activation of ecto-ATPases themself is capable of altering intracellular second-messengers (e.g. NO) thereby also affecting cell growth (Sneddon et al, 2000). To exclude a possible contribution of ecto-ATPases in the regulation of cell growth, the effects of the ecto-ATPase inhibitor ARL $67156(10-100 \mu \mathrm{M})$ were investi- gated. However, even $100 \mu \mathrm{M}$ of the ecto-ATPase inhibitor ARL 67156 showed no significant influence on proliferation of Kyse140 cells, thus excluding a contribution of ecto-ATPase signalling to the observed growth inhibitory effects (data not shown).

\section{Effects of extracellular nucleotides on the cell cycle}

To investigate if the observed growth inhibiting effects of extracellular nucleotides on oesophageal cancer cells were caused by cell cycle arrest, cell cycle analysis was performed. After sustained incubation of Kyse-140 cells with either ATP or $\mathrm{ATP} \gamma \mathrm{S}$ for $24 \mathrm{~h}$ a dose-dependent increase of the proportion of cells in the S-phase of the cell cycle was observed, indicating S-phase delay of the cells (Figure 1B). To exclude a possible contribution of breakdown products of ATP, in particular of adenosine, cell cycle analysis was performed with adenosine. In accordance with the proliferation data, adenosine (50$500 \mu \mathrm{M}$ ) did not alter the regulation of the cell cycle (data not shown).

\section{Apoptotic effects of extracellular nucleotides}

To check whether the antiproliferative effects of ATP and ATP $\gamma \mathrm{S}$, respectively, were caused not only by cell cycle arrest but also by an induction of programmed cell death, the activation of caspase-3, a key-enzyme in the process of apoptosis, was investigated in Kyse-140 cells. After $48 \mathrm{~h}$ of incubation ATP dose-
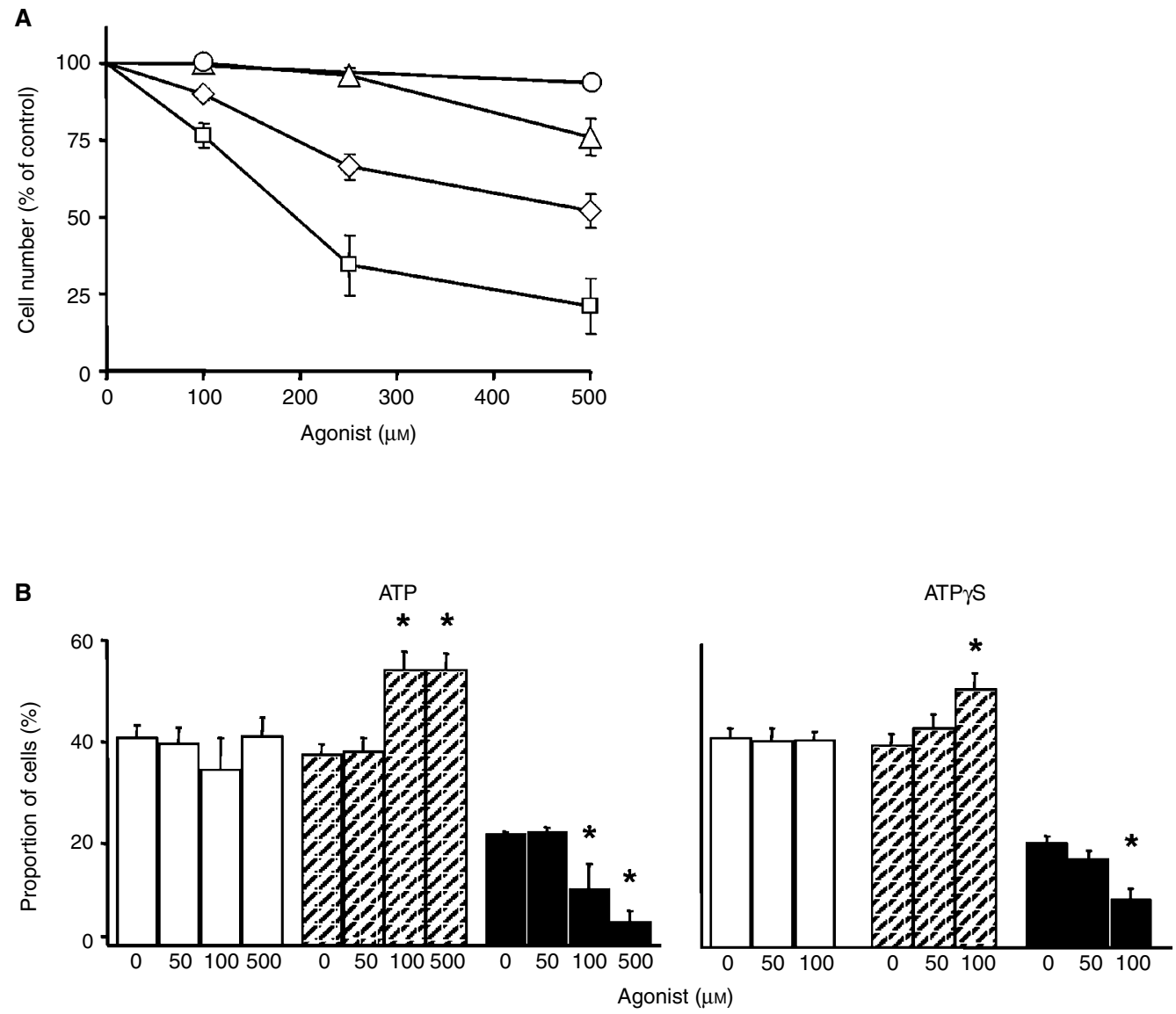

Figure I Antiproliferative and cell cycle effects of nucleotides. (A) Extracellular ATP $(\diamond)$ and ATP $\gamma(\square)$ significantly decreased the cell number of Kyse140 cells after 3 days of incubation in a dose-dependent manner $(P<0.05$ for $100-500 \mu \mathrm{M})$. In contrast, 2 MeSATP $(O)$ or adenosine $(\Delta)$ showed no or minor effects. The respective antiproliferative effects are given as the percentage of cells of the untreated controls $(=100 \%)$. Means \pm s.e.m. of four independent experiments are shown. (B) After $24 \mathrm{~h}$ of incubation both ATP and ATP $\gamma S$ altered the proportion of cells in the GI/G0-phase (white columns), Sphase (hatched columns), and G2/M-phase (black columns) of the cell cycle. Means \pm s.e.m. of six independent experiments are shown. 
dependently induced an increase of caspase-3 activity. With $500 \mu \mathrm{M}$ ATP the caspase- 3 activity was more than doubled compared to the untreated control (Figure 2A). ATP-induced caspase-3 activity was not due to a generation of adenosine, since adenosine (50$500 \mu \mathrm{M})$ failed to stimulate caspase-3 activity in Kyse-140 cells (data not shown). ATP $\gamma \mathrm{S}$ did not affect caspase-3 activity (Figure $2 \mathrm{~A})$. Three to $72 \mathrm{~h}$ of incubation with rising concentrations of ATP $\gamma \mathrm{S}(50-500 \mu \mathrm{M})$ did not evoke significant effects on caspase3 activity. To investigate a possible contribution of ecto-ATPasedependent generation of extracellular $\mathrm{P}_{\mathrm{i}}$ by degradation of ATP, which has already been shown to be involved in ATP-induced apoptosis (Zoeteweij et al, 1993), we pre-incubated the cells with $100 \mu \mathrm{M}$ of the ecto-ATPase-inhibitor ARL 67156. Under these conditions the ATP $(500 \mu \mathrm{M}$ for $48 \mathrm{~h})$ evoked induction of caspase- 3 activity decreased by $18 \pm 3.5 \%$ while ARL 67156 alone even increased caspase- 3 activity by $28 \pm 16 \%$. The data suggest that ecto-ATPase dependent generation of extracellular $\mathrm{P}_{\mathrm{i}}$ is involved in ATP-induced apoptosis of oesophageal cancer cells.

In primary oesophageal cancer cells induction of apoptosis by ATP was investigated by end-labelling of DNA with fluoresceindUTP (TUNEL assay). Fluorescence microscopy of primary cell cultures of oesophageal cancers treated with $500 \mu \mathrm{M}$ ATP for $48 \mathrm{~h}$ revealed an increase in apoptosis specific DNA strand breaks of $32.7 \pm 13 \%$ above the untreated control which showed an average proportion of apoptotic cells of $9.6 \pm 1.4 \%$. (Figure $2 \mathrm{~B}$ ).

\section{Expression of P2-receptor mRNA and protein}

To elucidate which P2-receptor subtype(s) may be responsible for the growth inhibiting and apoptotic effects of extracellular nucleotides, the mRNA expression of ionotropic P2-receptors $\left(\mathrm{P}_{2} \mathrm{X}_{1}\right.$, $\mathrm{P} 2 \mathrm{X}_{3}, \mathrm{P} 2 \mathrm{X}_{4}, \mathrm{P} 2 \mathrm{X}_{5}$, and $\mathrm{P} 2 \mathrm{X}_{7}$ ) and metabotropic $\mathrm{P} 2$-receptors $\left(\mathrm{P}_{1} \mathrm{Y}_{1}, \mathrm{P}_{2} \mathrm{Y}_{2}, \mathrm{P}_{2} \mathrm{Y}_{4}\right.$, and $\mathrm{P}_{2} \mathrm{Y}_{6}$ ) was investigated by $\mathrm{RT}-\mathrm{PCR}$. Kyse-140 cells expressed mRNAs of $\mathrm{P}_{2} \mathrm{X}_{4^{-}}, \mathrm{P}_{2} \mathrm{X}_{5^{-}}$, and $\mathrm{P}_{2} \mathrm{Y}_{2}$-receptors (Figure $3 \mathrm{~A}$ ). Interestingly, no mRNA-expression of $\mathrm{P}_{2} \mathrm{X}_{1^{-}}$or $\mathrm{P} 2 \mathrm{X}_{7}$-receptors, which are mainly implicated in the induction of apoptosis (Chow et al, 1997; Di Virgilio et al, 1998; Ferrari et al, 1999) was observed. The mRNA of $\mathrm{P}_{2} \mathrm{Y}_{2^{-}}$and $\mathrm{P}_{2} \mathrm{X}_{4}$ receptors was also detected in biopsies of human squamous cancers of the oesophagus, while transcripts of $\mathrm{P}_{2} \mathrm{X}_{1}$ and $\mathrm{P} 2 \mathrm{X}_{7}$ receptors were also missing in the mRNA of oesophageal cancer biopsies (Figure $4 \mathrm{~A}$ ).
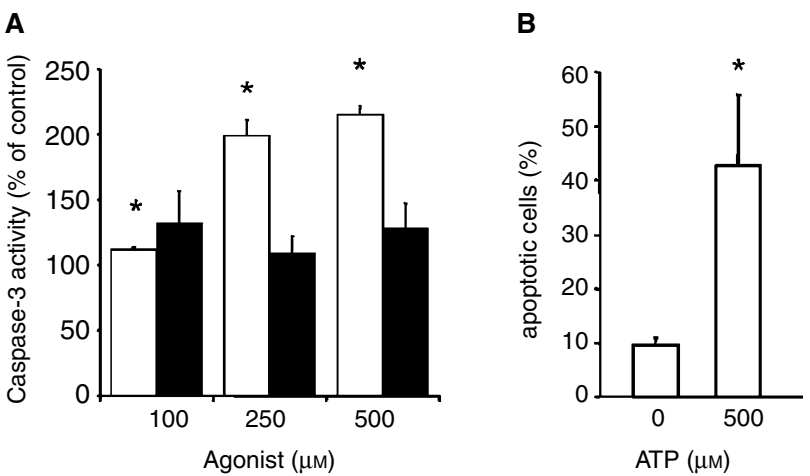

Figure 2 Apoptotic effects of extracellular nucleotides. (A) ATP (white columns) but not ATP $\gamma$ S (black columns) dose-dependently induced cas pase- 3 activity in Kyse- 140 cells after 48 h of incubation. Caspase- 3 activity was measured as the cleavage of the fluorogenic substrate DEVD-AM. Means + s.e.m. of four independent experiments are given as the percentage of fluorescence compared to untreated control. (B) Nucleic DNA fragmentation of human oesophageal primary culture cells was determined using TUNEL assay. Incubation with $500 \mu \mathrm{M}$ ATP for $48 \mathrm{~h}$ induced a significant increase of the proportion of nucleic fluorescence staining. The pro portions of positively stained cells are shown as means \pm s.e.m. of three independent preparations.
The specificity of PCR was confirmed by direct sequencing of transcripts (data not shown).

However, using immunocytochemistry only a $\mathrm{P}_{2} \mathrm{Y}_{2}$-receptorspecific fluorescence was detected in the membrane of either Kyse-140 and primary culture cells (Figure 3B,D), whereas neither Kyse-140 cells nor primary cell culture preparations showed any specific staining for $\mathrm{P}_{2} \mathrm{X}_{4}$ receptors (Figure $3 \mathrm{C}, \mathrm{E}$ ). Thus it is likely, that despite the mRNA expression of $\mathrm{P}_{2} \mathrm{X}_{4}$ receptors no translation into $\mathrm{P}_{2} \mathrm{X}_{4}$ protein occurs in the cells.

\section{Expression of functional P2-receptors}

To evaluate which P2-receptor subtypes mediate apoptosis and cell cycle arrest in oesophageal cancer cells, subtype-specific expression of functional P2-receptors was investigated by measuring changes in $\left[\mathrm{Ca}^{2+}\right]_{\mathrm{i}}$. In $\mathrm{Ca}^{2+}$-containing bath solution, ATP $(100 \mu \mathrm{M})$ induced a rapid biphasic increase of $\left[\mathrm{Ca}^{2+}\right]_{\mathrm{i}}$. An initial transient $\left[\mathrm{Ca}^{2+}\right]_{\mathrm{i}}$ peak was followed by a sustained plateau-phase (Figure 4A). Regardless of the omission of $\mathrm{Ca}^{2+}$ from the extracellular bath, ATP still induced a rapid but now only transient increase of $\left[\mathrm{Ca}^{2+}\right]_{\mathrm{i}}$ (Figure 4B). This observation suggests that the initial $\left[\mathrm{Ca}^{2+}\right]_{\mathrm{i}}$ peak was caused by the release of $\mathrm{Ca}^{2+}$ from intracellular stores, whereas the plateau-phase occurring under $\left[\mathrm{Ca}^{2+}\right]_{e^{-c o n t a i n}-}$ ing conditions was due to transmembraneous $\mathrm{Ca}^{2+}$-influx. The biphasic $\left[\mathrm{Ca}^{2+}\right]_{i}$ response to stimulation with ATP is a typical feature of metabotropic P2Y-receptors. Similar to ATP, UTP induced a comparable increase of $\left[\mathrm{Ca}^{2+}\right]_{\mathrm{i}}$ (Figure 4D), indicating the expression of purine and pyrimidine-sensitive receptors in oesophageal cancer cells. Pre-treatment of the cells with $100 \mu \mathrm{M}$ of either ATP or UTP prevented a second rise in $\left[\mathrm{Ca}^{2+}\right]_{i}$ in response to a consecutive stimulation with the respective other nucleotide (Figure 4C,D). This complete homologous cross-desensitization between ATP and UTP indicates that both nucleotides were competitively acting on a common binding site. Since only one metabotropic P2Y-receptor equipotently activated by either ATP or UTP, is known so far, these data strongly suggest the functional expression of $\mathrm{P}_{2} \mathrm{Y}_{2}$-receptors in Kyse-140 cells.

For further pharmacological characterization, a possible contribution of P2X-receptors to the observed changes in $\left[\mathrm{Ca}^{2+}\right]_{i}$ was investigated by using the P2X-receptor specific agonists 2methylthio-ATP (2MeSATP) and $\alpha, \beta$-methylene-ATP $(\alpha, \beta$ meATP). $\mathrm{P}_{2} \mathrm{Y}_{1^{-}}, \mathrm{P}_{2} \mathrm{Y}_{11^{-}}, \mathrm{P}_{2} \mathrm{Y}_{\mathrm{ADP}^{-}}$and the ionotropic $\mathrm{P} 2 \mathrm{X}_{1-6^{-}}$ receptors have been shown to be sensitive for 2MeSATP (Lambrecht, 2000). However, $100 \mu \mathrm{M}$ 2MeSATP did not evoke any increase of $\left[\mathrm{Ca}^{2+}\right]_{\mathrm{i}}$ in Kyse-140 cells (Figure $4 \mathrm{E}$ ). Even at the high concentration of $500 \mu \mathrm{M}, 2 \mathrm{MeSATP}$ showed no $\left[\mathrm{Ca}^{2+}\right]_{\mathrm{i}}$-inducing effects (data not shown). However, it has been shown by others (Weidema et al, 2001), that activation of $\mathrm{P}_{2} \mathrm{X}_{4}$-receptors does not necessarily influence $\left[\mathrm{Ca}^{2+}\right]_{\mathrm{i}}$ but is implicated in alterations of intracellular sodium concentrations $\left(\left[\mathrm{Na}^{+}\right]_{\mathrm{i}}\right)$. Therefore additional $\left[\mathrm{Na}^{+}\right]_{\mathrm{i}}$-measurements with 2MeSATP were performed. Nevertheless, applying $100 \mu \mathrm{M}$ 2MeSATP on Kyse-140 cells, preloaded with the $\left[\mathrm{Na}^{+}\right]_{\mathrm{i}^{-}}$-sensitive dye SBFI $(10 \mu \mathrm{M})$, did not evoke alterations in $\left[\mathrm{Na}^{+}\right]_{\mathrm{i}}$ (Figure 5). Comparable negative results were obtained by applying ATP or UTP $(100 \mu \mathrm{M})$ (data not shown). As positive control the cells were treated with $10 \mu \mathrm{M}$ gramicidin at the end of each experiment. Gramicidin is known to perforate the cell membrane to become sodium-permeable (Diarra et al, 2001). Gramicidin treatment always led to an increase of $\left[\mathrm{Na}^{+}\right]_{i}$ (Figure 5). In line with the negative results of $\mathrm{P}_{2} \mathrm{X}_{4}$ immunocytochemistry our data suggest, that despite the mRNA expression of $\mathrm{P}_{2} \mathrm{X}_{4}$-receptors, neither protein nor functional $\mathrm{P} 2 \mathrm{X}_{4}$ receptor expression occurred in Kyse-140 cells.

As expected by the negative results of RT-PCR for the mRNAexpression of $\mathrm{P} 2 \mathrm{X}_{1}$ and $\mathrm{P} 2 \mathrm{X}_{7}$ receptors, no increase in $\left[\mathrm{Ca}^{2+}\right]_{\mathrm{i}}$ was observed when the cells were challenged by the P2X-receptor agonist $\alpha, \beta$-meATP, which additionally excluded a contribution of these receptor subtypes in the observed apoptotic and cell cycle 
A

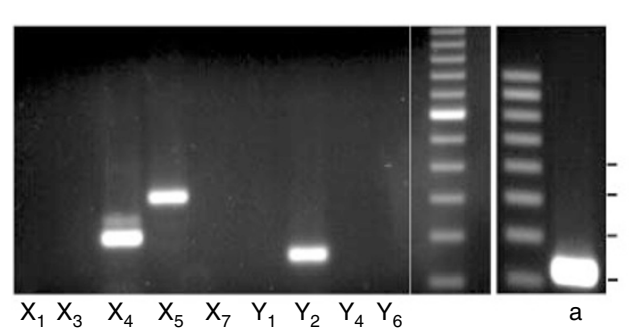

Kyse-140
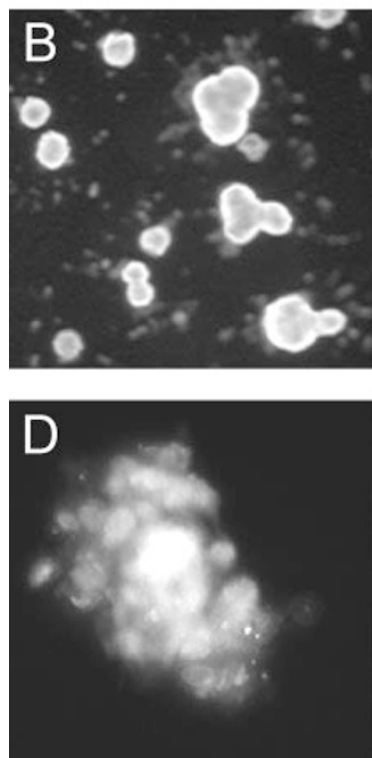
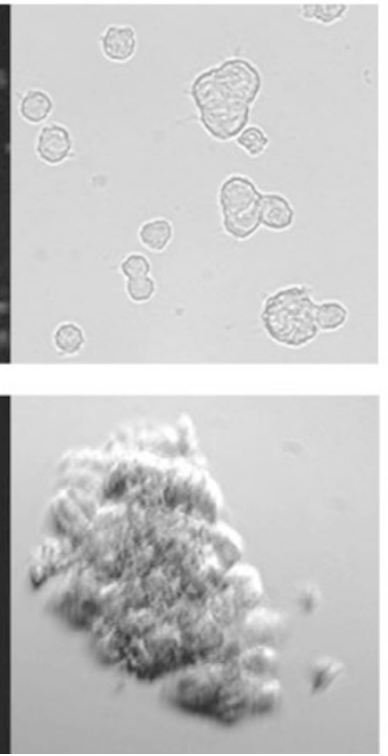
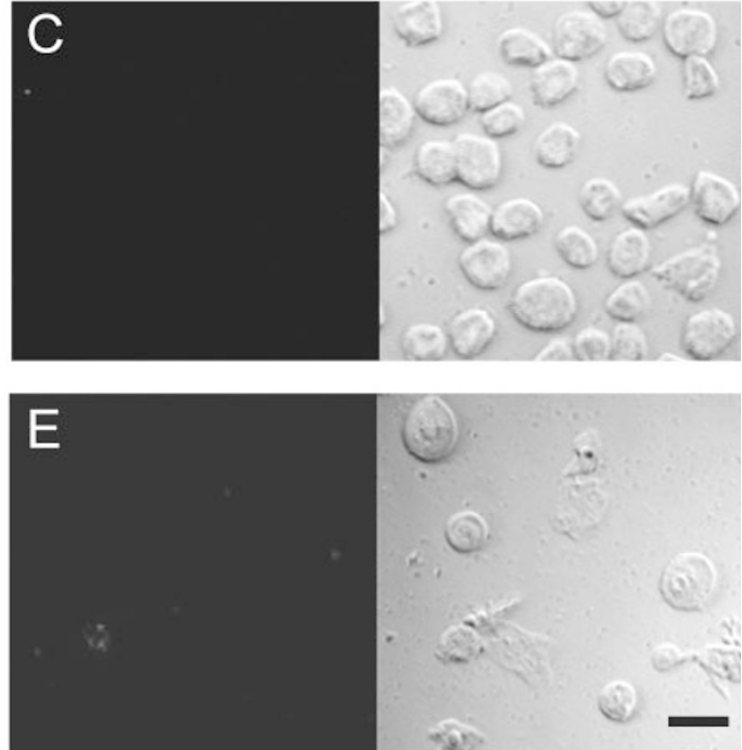

Figure 3 Expression of P2-receptor subtypes. (A) Detection of mRNAs of ionotropic and metabotropic P2-receptor subtypes and of $\beta$-actin (a) in Kyse140 cells as well as in oesophageal primary cell cultures by reverse transcriptase polymerase chain reaction (RT - PCR). Transcripts of two representative primary cell cultures (I and 2) out of four are shown. Amplified cDNA was visualised by gel electrophoresis on an ethidium-bromide-stained agarose gel. (B-E) Kyse- I 40 cells $(\mathbf{B}, \mathbf{C})$ or oesophageal primary culture cells $(\mathbf{D}, \mathbf{E})$ were incubated with either specific P2Y 2 antibody $(\mathbf{B}, \mathbf{D})$ or P2X 4 antibody $(\mathbf{C}, \mathbf{E})$ and subsequently with secondary fluorescence-labelled antibody. Left side: fluorescence images, right side: corresponding transmission light images. $\mathrm{Bar}=20 \mu \mathrm{M}$.

arresting effects on oesophageal cancer cells. To conclude, the rank order of potency of the applied nucleotides to increase $\left[\mathrm{Ca}^{2+}\right]_{i}$ was $\mathrm{ATP}=\mathrm{UTP}>\mathrm{ATP} \gamma \mathrm{S}>\mathrm{ADP}=\mathrm{UDP}>>2 \mathrm{MeSATP}=\alpha, \beta$-meATP. This graded efficiency of different nucleotides to increase $\left[\mathrm{Ca}^{2+}\right]_{i}$ reflects the pharmacological pattern of $\mathrm{P}_{2} \mathrm{Y}_{2}$-receptors, which thus seems to be the only functionally expressed P2-receptor subtype in squamous oesophageal cancer cells.

$\mathrm{P}_{2} \mathrm{Y}_{2}$-receptors couple to phospholipase $\mathrm{C}$ via $\mathrm{G}_{\mathrm{q} / 11}$ proteins (Burnstock, 1997). To determine the role of phospholipase C in the signalling pathway of $\mathrm{P}_{2} \mathrm{Y}_{2}$-receptors in Kyse-140 cells, the specific phospholipase C inhibitor U73122 was used. U73122 dose-dependently inhibited the increase of $\left[\mathrm{Ca}^{2+}\right]_{i}$ upon ATP stimulation at micromolar concentrations, whereas its inactive analogue U73343 showed little if any effect (Figure 6). Fifty $\mu \mathrm{M}$ U73122 completely suppressed the ATP induced $\left[\mathrm{Ca}^{2+}\right]_{\mathrm{i}}$-rises, confirming that in Kyse-140 cells $\mathrm{P}_{2} \mathrm{Y}_{2}$-receptors couple to phospholipase $\mathrm{C}$ and thereby effect $\left[\mathrm{Ca}^{2+}\right]_{\mathrm{i}}$-rises.

\section{DISCUSSION}

ATP is released from malignant cells in response to chemo- or radiotherapy. Extracellular ATP is known to inhibit growth of Ehrlich ascites tumour cells, colon cancer, ovarian cancer, endo- metrial cancer, breast cancer, and fibroblast cell lines (Estrela et al, 1995; Correale et al, 1997; Höpfner et al, 1998; Katzur et al, 1999; Li et al, 2000; Schultze-Mosgau et al, 2000). Here we provide evidence that extracellular nucleotides induce apoptosis and cause cell cycle arrest in human squamous cancer cells of the oesophagus.

ATP and ATP $\gamma S$ induced a delay in the S-phase of the cell cycle. The cell cycle arresting effects of extracellular nucleotides were similar to the ones elicited by the cytostatic drugs 5-fluorouracil and cisplatin in oesophageal cancer cells (Yamane et al, 1999; Mastbergen et al, 2000). Moreover, for breast and ovarian cancer a positive correlation between S-phase fraction and the response to anticancer agents has recently been documented (Chevillard et al, 1996; Kolfschoten et al, 2000). Hence, recruitment of cancer cells to the S-phase of the cell cycle by ATP might sensitise oesophageal cancer cells to a reinforced response to established chemotherapeutic drugs. Furthermore, cyclin-dependent kinase inhibitors such as flavopiridol, a promising new class of anticancer drugs, showed enhanced cytotoxity at cells arrested in the S-phase (Shapiro and Harper, 1999). Hence, in addition to the antiproliferative action of ATP on its own, possible synergistic effects of ATP and anticancer drugs will be interesting to investigate. Accordingly, a synergistic antiproliferative effect of 5-FU and extracellular ATP 
642

A

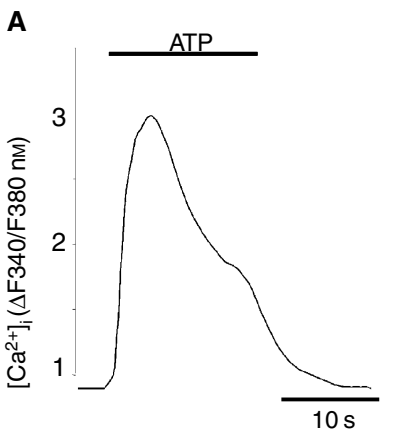

C

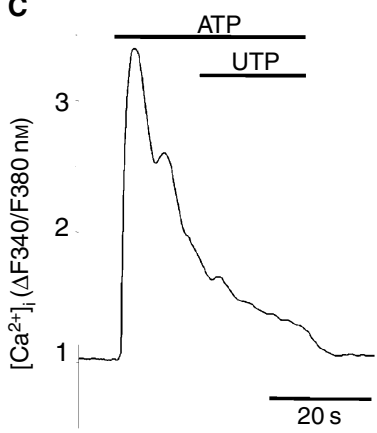

E

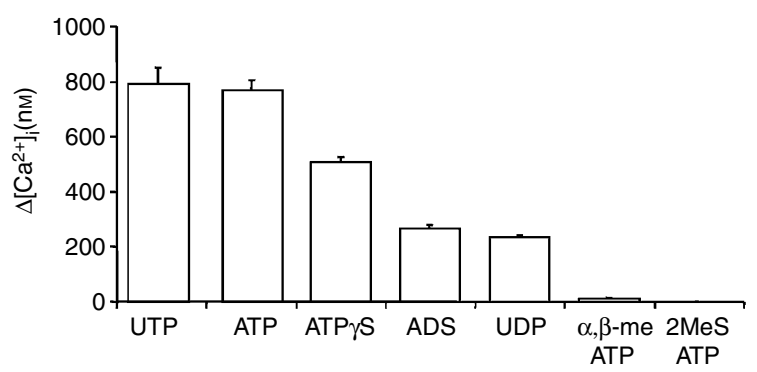

Figure 4 Functional expression of P2-receptors. (A) Biphasic increase of $\left[\mathrm{Ca}^{2+}\right]_{\mathrm{i}}$ after ATP application ( $\left.100 \mu \mathrm{M}\right)$ in $\mathrm{Ca}^{2+}$-containing bath solution. (B) Monophasic $\left[\mathrm{Ca}^{2+}\right]_{\text {i }}$ rise after ATP application $(100 \mu \mathrm{M})$ in $\mathrm{Ca}^{2+}$-free solution. (C) Application of UTP (I00 $\mu \mathrm{M})$ during prolonged ATP stimulation (I00 $\mu \mathrm{M}$ ) failed to elicit any further response. (D) Application of ATP $(100 \mu \mathrm{M})$ during prolonged UTP stimulation (I00 $\mu \mathrm{M})$ did not cause any further rise of $\left[\mathrm{Ca}^{2+}\right]_{i}$. The $\left[\mathrm{Ca}^{2+}\right]_{i}$ is given as the fluorescence ratio $(\Delta \mathrm{F} 340 / \mathrm{F} 380 \mathrm{~nm})$ of the $\mathrm{Ca}^{2+}$-sensitive dye fura-2. Representative singlecell tracings out of three independent experiments with 20 or more cells per incubation are shown. (E) Different nucleotides in equimolar concentration $(100 \mu \mathrm{M})$ induced distinct increases of $\left[\mathrm{Ca}^{2+}\right]_{i}$ in KYSE-I 40 cells measured under $\left[\mathrm{Ca}^{2+}\right]$-containing conditions. Values are given as the peak increase above basal $\left[\mathrm{Ca}^{2+}\right]_{i}$ of resting cells. The basal level of resting cells amounted to $58 \pm 7$ nM. Means \pm s.e.m. of 44 to 98 cells per nucleotide are shown.

has recently been described in colorectal carcinoma cells (Höpfner et al, 2001).

Besides its cell cycle interfering effects, ATP was shown to induce apoptosis in oesphageal cancer cells as assessed by TUNEL assays and measuring increases of caspase- 3 activity. Both primary cell cultures and Kyse-140 cells were shown to undergo apoptosis upon ATP treatment. The ability of ATP to induce apoptosis via $\mathrm{P} 2$-receptors in a $\left[\mathrm{Ca}^{2+}\right]_{\mathrm{i}}$-dependent manner has been formerly demonstrated by others (Chow et al, 1997). On the other hand, using the hydrolysis resistant ATP derivative ATP $\gamma \mathrm{S}$, Katzur et al (1999) observed $\mathrm{P}_{2} \mathrm{Y}_{2}$-mediated antiproliferative but not apoptosis inducing effects in endometrial carcinoma cells. In our study both

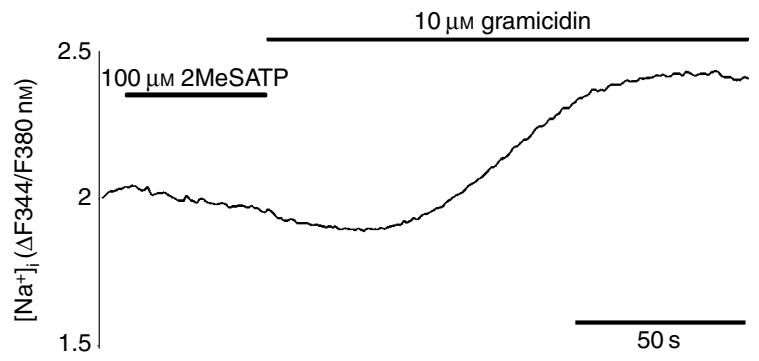

Figure 5 Effect of 2MeSATP on $\left[\mathrm{Na}^{+}\right]_{\mathrm{i} .}$. Incubation of Kyse-I 40 cells with $100 \mu \mathrm{M}$ 2MeSATP did not alter $\left[\mathrm{Na}^{+}\right]_{\text {i }}$, whereas application of gramicidin markedly increased $\left[\mathrm{Na}^{+}\right]_{i}$. $\left[\mathrm{Na}^{+}\right]_{i}$ is given as the fluorescence ratio $(\Delta \mathrm{F} 344 / \mathrm{F} 380 \mathrm{~nm})$ of the $\mathrm{Na}^{+}$-sensitive dye SBFI/AM. Representative single-cell tracing out of three independent experiments with 18 or more cells per experiment is shown.

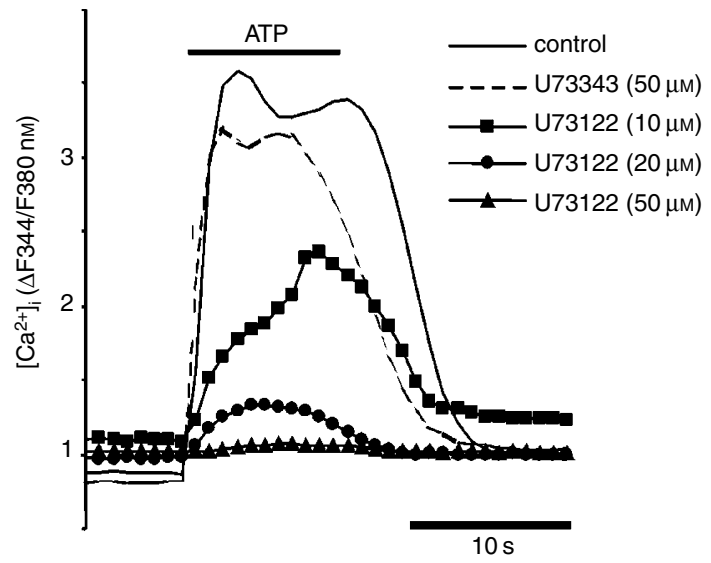

Figure 6 Phospholipase $C$ pathway. $P 2 Y_{2}$-receptor mediated $\left[\mathrm{Ca}^{2+}\right]_{\mathrm{i}}$ elevations in Kyse- I40 cells are mediated by phospholipase $C$ activation Pre-treatment ( $10 \mathrm{~min}$ ) of Kyse- 140 cells with the phospholipase $C$ inhibitor U73 $22(10-50 \mu \mathrm{M})$ dose-dependently inhibited $\left[\mathrm{Ca}^{2+}\right]_{\mathrm{i}}$ elevation in response to ATP $(100 \mu \mathrm{M})$, whereas the inactive U73|22-analogue U73343 $(50 \mu \mathrm{M})$ did not affect P2Y ${ }_{2}$-receptor mediated $\left[\mathrm{Ca}^{2+}\right]_{\mathrm{i}}$ signalling. $\left[\mathrm{Ca}^{2+}\right]_{i}$ is given as the fluorescence ratio $(\Delta \mathrm{F} 340 / \mathrm{F} 380 \mathrm{~nm})$ of the $\mathrm{Ca}^{2+}$ sensitive dye fura-2. Representative single-cell tracings out of five independent experiments with 20 or more cells per incubation are shown.

nucleotides, ATP and the ATP $\gamma \mathrm{S}$, evoked rises of $\left[\mathrm{Ca}^{2+}\right]_{i}$, but only ATP induced apoptosis. This suggests that in addition to the $\mathrm{P}_{2} \mathrm{Y}_{2-}$ receptor triggered $\left[\mathrm{Ca}^{2+}\right]_{i}$-increase other signalling pathways may mediate apoptosis of oesophageal cancer cells in response to ATP. Interestingly, Zoeteweij et al (1993) showed that in hepatocytes $\left[\mathrm{Ca}^{2+}\right]_{\mathrm{i}}$-induced apoptosis after prolonged exposure to ATP was dependent on the generation of extracellular inorganic phosphate $\left(\mathrm{P}_{\mathrm{i}}\right)$, which resulted from an ecto-ATPase mediated hydolysis of the applied extracellular ATP. Hence, inorganic phosphate might be an additional signal necessary to induce apoptosis in oesophageal cancer cells. Since ATP is hydrolyzed by ubiquitously expressed ecto-ATPases and ectonucleotidases, this could explain, why the hydrolysis resistant ATP derivative ATP $\gamma \mathrm{S}$, which is additionally known to be an effective ecto-ATPase-inhibitor (Chen and Lin, 1997), failed to induce apoptosis specific caspase3 activation in oesophageal cancer cells. This interpretation was supported by our finding that the ecto-ATPase-inhibitor ARL 67156, which diminished the generation of $\mathrm{P}_{\mathrm{i}}$ by inhibiting ATPdegradation, resulted in a reduced activation of ATP induced caspase-3 activity.

Antiproliferative as well as apoptosis inducing actions of extracellular nucleotides are thought to result from (prolonged) 
stimulation of functionally expressed P2-receptors. While antiproliferative effects of metabotropic P2Y-receptors have been documented in various tumour models (Fang et al, 1992; Vandewalle et al, 1994; Höpfner et al, 1998; Katzur et al, 1999; Schultze-Mosgau et al, 2000), apoptosis inducing effects of P2Yreceptors have only been shown in MCF-7-breast cancer (Vandewalle et al, 1994) and colorectal carcinoma cells (Höpfner et al, 2001) so far. Here we provide evidence that the cell cycle arresting and apoptosis inducing actions of ATP involved the activation of $\mathrm{P}_{2} \mathrm{Y}_{2}$-receptors in oesophageal cancer cells. Expression of $\mathrm{P}_{2} \mathrm{Y}_{2}-$ receptors in primary culture cells of oesophageal cancers as well as in Kyse-140 cells was revealed by both RT-PCR and by immunocytochemistry. Performing $\left[\mathrm{Ca}^{2+}\right]_{\mathrm{i}}$-imaging Kyse-140 cells were shown to be equally sensitive to both purine and pyrimidine nucleotides demonstrating the functionality of the expressed $\mathrm{P}_{2} \mathrm{Y}_{2}$ receptor protein. The functional expression of the $\mathrm{P}_{2} \mathrm{Y}_{2}$-receptor subtype was strengthened by the complete cross-desensitization between the two major agonists, ATP and UTP. Furthermore, the increase of $\left[\mathrm{Ca}^{2+}\right]_{\mathrm{i}}$ was shown to be PLC-dependent, indicating that the induction of $\left[\mathrm{Ca}^{2+}\right]_{\mathrm{i}}$ was mediated by $\mathrm{G}_{\mathrm{q} / 11^{-}}$-coupled and PLC-linked metabotropic $\mathrm{P}_{2} \mathrm{Y}_{2}$-receptors.

However, the main P2-receptor subtypes implicated in apoptosis are ionotropic $\mathrm{P} 2 \mathrm{X}$-receptors of the subtypes $\mathrm{P}_{2} \mathrm{X}_{1}$ and $\mathrm{P} 2 \mathrm{X}_{7}$ (Chvatchko et al, 1996; Di Virgilio et al, 1998; Ferrari et al, 1999). P2X-receptors are mainly found in excitable tissues such as smooth muscles and nerves, although $\mathrm{P}_{2} \mathrm{X}_{4}$-receptors have also been reported in endocrine tissues (Ralevic and Burnstock, 1998). However, neither in primary cultures of oesophageal cancers nor in the oesophageal cancer cell line Kyse-140 mRNA expression of either $\mathrm{P}_{2} \mathrm{X}_{1}$ - or $\mathrm{P} 2 \mathrm{X}_{7}$-receptors could be detected. Only transcripts of the ionotropic $\mathrm{P} 2$-receptor subtypes $\mathrm{P}_{2} \mathrm{X}_{4}$ and $\mathrm{P} 2 \mathrm{X}_{5}$ were found. So far neither $\mathrm{P}_{2} \mathrm{X}_{4}$ nor $\mathrm{P}_{2} \mathrm{X}_{5}$ has been implicated in the induction of apoptosis. Moreover, the functional expression of $\mathrm{P}_{2} \mathrm{X}_{5}$-receptors is most unlikely, since the human $\mathrm{P}_{2} \mathrm{X}_{5}$-receptors described are unable to form functional channels (North and Surprenant, 2000). Nevertheless, to examine the possible expression and functionality of $\mathrm{P}_{2} \mathrm{X}_{4}$-receptors in oesophageal cancer cells immunocytochemistry, $\left[\mathrm{Ca}^{2+}\right]_{\mathrm{i}^{-}}$and $\left[\mathrm{Na}^{+}\right]_{\mathrm{i}^{-}}$-measurements were performed. Immunofluorescence microscopy with the specific $\mathrm{P}_{2} \mathrm{X}_{4}$-receptor antibody $\mathrm{Ab}-1$ failed to yield a $\mathrm{P}_{2} \mathrm{X}_{4}$-receptor staining in either primary cultured cells or in the squamous oesophageal cancer cell line Kyse-140. Also the application of the $\mathrm{P}_{2} \mathrm{X}_{4}$-receptor-specific agonist 2MeSATP failed to alter $\left[\mathrm{Ca}^{2+}\right]_{\mathrm{i}}$. Since it has been reported

\section{REFERENCES}

Agteresch HJ, Dagnelie PC, van den Berg JW, Wilson JH (1999) Adenosine triphosphate: established and potential clinical applications. Drugs 58: $211-232$

Barnard EA, Burnstock G, Webb TE (1994) G protein-coupled receptors for ATP and other nucleotides: a new receptor family. Trends Pharmacol Sci 15: $67-70$

Berridge MJ (1995) Capacitative calcium entry. Biochem J 312: 1-11

Bronte V, Macino B, Zambon A, Rosato A, Mandruzzato S, Zanovello P, Collavo D (1996) Protein tyrosine kinases and phosphatases control apoptosis induced by extracellular adenosine $5^{\prime}$-triphosphate. Biochem Biophys Res Commun 218: $344-351$

Burnstock G (1978) Cell membrane receptors for drugs and hormones. A multi disciplinary approach. In Cell Membrane Receptors for Drugs and Hormones. A Multi Disciplinary Approach Straub RW, Bolis L (eds) pp 107-118 New York: Raven Press

Burnstock G (1997) The past, present and future of purine nucleotides as signalling molecules. Neuropharmacology 36: 1127-1139

Chen BC, Lin WW (1997) Inhibition of ecto-ATPase by the P2 purinoceptor agonists, ATPgammaS, alpha,beta-methylene-ATP, and AMP-PNP, in endothelial cells. Biochem Biophys Res Commun 233: 442-446 that in osteoclasts $\mathrm{P} 2 \mathrm{X}_{4}$-receptors do not couple to $\left[\mathrm{Ca}^{2+}\right]_{\mathrm{i}}$-signalling but influence $\left[\mathrm{Na}^{+}\right]_{\mathrm{i}}$ (Weidema et al, 2001), we performed $\left[\mathrm{Na}^{+}\right]_{\mathrm{i}}$-measurements. However, 2MeSATP induced alterations of $\left[\mathrm{Na}^{+}\right]_{\mathrm{i}}$ could not be detected. Thus, on the basis of our data we exclude protein and functional expression of $\mathrm{P}_{2} \mathrm{X}_{4}$-receptors in oesophageal cancer cells - despite positive RT-PCR-findings. Altogether, P2X-receptors do not appear to contribute to ATPinduced $\left[\mathrm{Ca}^{2+}\right]_{\mathrm{i}}$-signalling or to growth inhibition and apoptosis in Kyse-140 oesophageal cancer cells.

To ensure that the observed antiproliferative effects of extracellular nucleotides on oesophageal cancer cells were actually $\mathrm{P}_{2} \mathrm{Y}_{2}-$ receptor mediated events and were not caused by unspecific effects of the applied nucleotides we also performed proliferation assays with the $\mathrm{P}_{2} \mathrm{X}_{4}$-receptor agonist $2 \mathrm{MeSATP}$. Since we have excluded a functional expression of $\mathrm{P}_{2} \mathrm{X}_{4}$-receptors in the investigated oesophageal cancer cells and it is known that 2MeSATP does not activate $\mathrm{P}_{2} \mathrm{Y}_{2}$-receptors to a relevant extent (Ralevic and Burnstock, 1998), only unspecific signalling of the applied nucleotide could yield antiproliferative effects. However, no contribution of 2MeSATP on the growth of oesophageal cancer cells could be observed - even at a concentration of $500 \mu \mathrm{M}$. These data suggest that the induction of growth inhibition and apoptosis in oesophageal cancer cells by extracellular ATP and ATP $\gamma S$ was caused by the activation of $\mathrm{P}_{2} \mathrm{Y}_{2}$-receptors, but was not due to unspecific effects of these extracellular nucleotides.

To conclude, our data show that extracellular nucleotides cause cell cycle arrest and induce apoptosis in human oesophageal carcinoma cells. These actions are mediated by $\mathrm{P}_{2} \mathrm{Y}_{2}$-receptors. Interestingly, ATP has already been studied as an anti-cachexia and antiproliferative agent in advanced lung-cancer (Haskell et al, 1996; Agteresch et al, 1999). Taken together, we therefore think that $\mathrm{P}_{2} \mathrm{Y}_{2}$-receptors may qualify as promising targets for innovative treatment strategies of oesophageal cancer.

\section{ACKNOWLEDGEMENTS}

We are indebted to Dr BK Kishore for kindly providing us with the anti-P2Y 2 antibody. We thank the Institute of Physiology, FU Berlin for lab facilities and B Jebautzke for expert technical assistance. This study was supported by the Mildred Scheel Stiftung and the Deutsche Forschungsgemeinschaft.
Chevillard S, Pouillart P, Beldjord C, Asselain B, Beuzeboc P, Magdelenat H, Vielh P (1996) Sequential assessment of multidrug resistance phenotype and measurement of S-phase fraction as predictive markers of breast cancer response to neoadjuvant chemotherapy. Cancer 77: 292-300

Chow SC, Kass GE, Orrenius S (1997) Purines and their roles in apoptosis. Neuropharmacology 36: 1149-1156

Chvatchko Y, Valera S, Aubry JP, Renno T, Buell G, Bonnefoy JY (1996) The involvement of an ATP-gated ion channel, $\mathrm{P}(2 \mathrm{X} 1)$, in thymocyte apoptosis. Immunity 5: $275-283$

Correale P, Tagliaferri P, Guarrasi R, Caraglia M, Giuliano M, Marinetti MR, Bianco AR, Procopio A (1997) Extracellular adenosine 5' triphosphate involvement in the death of LAK-engaged human tumor cells via P2Xreceptor activation. Immunol Lett 55: 69-78

Diarra A, Sheldon C, Church J (2001) In situ calibration and $\left[\mathrm{H}^{+}\right]$sensitivity of the fluorescent $\mathrm{Na}^{+}$indicator SBFI. Am J Physiol Cell Physiol 280: C1623-C1633

Di Virgilio F, Chiozzi P, Falzoni S, Ferrari D, Sanz JM, Venketaraman V, Baricordi OR (1998) Cytolytic P2X purinoceptors. Cell Death Differ 5: $191-199$ 
Dubyak GR, el-Moatassim C (1993) Signal transduction via P2-purinergic receptors for extracellular ATP and other nucleotides. Am J Physiol 265: C577-C606

Duncan G, Riach RA, Williams MR, Webb SF, Dawson AP, Reddan JR (1996) Calcium mobilisation modulates growth of lens cells. Cell Calcium 19: $83-$ 89

Estrela JM, Obrador E, Navarro J, Lasso de la Vega MC, Pellicer JA (1995) Elimination of Ehrlich tumours by ATP-induced growth inhibition, glutathione depletion and X-rays. Nat Med 1: 84-88

Fang WG, Pirnia F, Bang YJ, Myers CE, Trepel JB (1992) P2-purinergic receptor agonists inhibit the growth of androgen-independent prostate carcinoma cells. J Clin Invest 89: 191-196

Ferrari D, Los M, Bauer MK, Vandenabeele P, Wesselborg S, Schulze-Osthoff K (1999) P2Z purinoreceptor ligation induces activation of caspases with distinct roles in apoptotic and necrotic alterations of cell death. FEBS Let 447: $71-75$

Fredholm BB, Abbracchio MP, Burnstock G, Daly JW, Harden TK, Jacobson KA, Leff P, Williams M (1994) Nomenclature and classification of purinoceptors. Pharmacol Rev 46: $143-156$

Fredholm BB, Abbracchio MP, Burnstock G, Dubyak GR, Harden TK, Jacobson KA, Schwabe U, Williams M (1997) Towards a revised nomenclature for P1 and P2 receptors. Trends Pharmacol Sci 18: 79-82

Gillies RJ, Didier N, Denton M (1986) Determination of cell number in monolayer cultures. Anal Biochem 159: 109-113

Glassmeier G, Herzig KH, Höpfner M, Lemmer K, Jansen A, Scherübl H (1998) Expression of functional $\mathrm{GABA}_{\mathrm{A}}$ receptors in cholecystokininsecreting gut neuroendocrine murine STC-1 cells. J Physiol (Lond) 510: $805-814$

Grynkiewicz G, Poenie M, Tsien RY (1985) A new generation of $\mathrm{Ca}^{2+}$ indicators with greatly improved fluorescence properties. J Biol Chem 260: $3440-3450$

Haskell CM, Wong M, Williams A, Lee LY (1996) Phase I trial of extracellulary adenosine $5^{\prime}$-triphosphate in patients with advanced cancer. Med Pedriatr Oncol 27: 165-173

Höpfner M, Lemmer K, Jansen A, Hanski C, Riecken EO, Gavish M, Mann B, Buhr H, Glassmeier G, Scherübl H (1998) Expression of functional P2purinergic receptors in primary cultures of human colorectal carcinoma cells. Biochem Biophys Res Commun 251: 811-817

Höpfner M, Maaser K, von Lampe B, Barthel B, Hanski C, Riecken E-O, Zeitz M, Scherübl H (2001) Growth inhibition and apoptosis induced by $\mathrm{P}_{2} \mathrm{Y}_{2-}$ receptors in human colorectal carcinoma cells: Involvement of intracellular calcium and cyclic AMP. Int J Colorectal Dis 16: 154-166

Ishikawa S, Higashiyama M, Kusaka I, Saito T, Nagasaka S, Fukuda S (1997) Extracellular ATP promotes cellular growth of renal inner medullary collecting duct cells mediated via P2u receptors. Nephron 76: $208-214$

Katzur AC, Koshimizu T, Tomic M, Schultze-Mosgau A, Ortmann O, Stojilkovic SS (1999) Expression and responsiveness of $\mathrm{P}_{2} \mathrm{Y}_{2}$ receptors in human endometrial cancer cell lines. J Clin Endocrinol Metab 84: 4085 4091

Kishore BK, Ginns SM, Krane CM, Nielsen S, Knepper MA (2000) Cellular localization of $\mathrm{P} 2 \mathrm{Y}(2)$ purinoceptor in rat renal inner medulla and lung. Am J Physiol Renal Physiol 278: F43 - F51

Kolfschoten GM, Hulscher TM, Pinedo HM, Boven E (2000) Drug resistance features and S-phase fraction as possible determinants for drug response in a panel of human ovarian cancer xenografts. Br J Cancer 83: 921 - 927

Lambrecht G (2000) Agonists and antagonists acting at P2X receptors: selectivity profiles and functional implications. Naunyn Schmiedebergs Arch Pharmacol 362: $340-350$

Li JW, Inoue Y, Miyazaki M, Pu H, Kondo A, Namba M (2000) Growth inhibitory effects of ATP and its derivatives on human fibroblasts immortalized with 60Co-gamma rays. Int J Mol Med 5: 59-62

Li X, Melamed MR, Darzynkiewicz Z (1996) Detection of apoptosis and DNA replication by differential labeling of DNA strand breaks with fluorochromes of different color. Exp Cell Res 222: 28-37
Lytton J, Westlin M, Hanley MR (1991) Thapsigargin inhibits the sarcoplasmic or endoplasmic reticulum Ca-ATPase family of calcium pumps. J Biol Chem 266: $17067-17071$

Maaser K, Höpfner M, Jansen A, Weisinger G, Gavish M, Kozikowski AP, Weizman A, Carayon P, Riecken EO, Zeitz M, Scherübl H (2001) Specific ligands of the peripheral benzodiazepine receptor induce apoptosis and cell cycle arrest in human colorectal cancer cells. Br J Cancer 85: 1771-1780

Mastbergen SC, Duivenvoorden I, Versteegh RT, Geldof AA (2000) Cell cycle arrest and clonogenic tumor cell kill by divergent chemotherapeutic drugs. Anticancer Res 20: $1833-1838$

McConkey DJ, Orrenius S (1997) The role of calcium in the regulation of apoptosis. Biochem Biophys Res Commun 239: 357-366

Morgan AJ, Thomas AP (1999) Single cell and subcellular measurement of intracellular $\mathrm{Ca}^{2+}$ concentration $\left(\left[\mathrm{Ca}^{2+}\right]_{\mathrm{i}}\right)$. In Calcium Signaling Protocols Lambert DG (ed) pp 93-123 Totowa, New Jersey: Humana Press Inc.

Nicholson DW, Ali A, Thornberry NA, Vaillancourt JP, Ding CK, Gallant M, Gareau Y, Griffin PR, Labelle M, Lazebnik YA (1995) Identification and inhibition of the ICE/CED-3 protease necessary for mammalian apoptosis [see comments]. Nature 376: 37-43

North RA, Surprenant A (2000) Pharmacology of cloned P2X receptors. Annu Rev Pharmacol Toxicol 40: $563-580$

Ralevic V, Burnstock G (1998) Receptors for purines and pyrimidines. Pharmacol Rev 50: 413-492

Rapaport E (1990) Mechanisms of anticancer activities of adenine nucleotides in tumor-bearing hosts. Ann NY Acad Sci 603: 142-149 discussion 149150: $142-149$

Roman RM, Fitz JG (1999) Emerging roles of purinergic signaling in gastrointestinal epithelial secretion and hepatobiliary function. Gastroenterology 116: $964-979$

Schöfl C, Ponczek M, Mader T, Waring M, Benecke H, von zur Mühlen, Mix H, Cornberg M, Boker KH, Manns MP, Wagner S (1999) Regulation of cytosolic free calcium concentration by extracellular nucleotides in human hepatocytes. Am J Physiol 276: G164-G172

Schultze-Mosgau A, Katzur AC, Arora KK, Stojilkovic SS, Diedrich K, Ortmann O (2000) Characterization of calcium-mobilizing, purinergic P2Y(2) receptors in human ovarian cancer cells. Mol Hum Reprod 6: $435-442$

Shapiro GI, Harper JW (1999) Anticancer drug targets: cell cycle and checkpoint control. J Clin Invest 104: $1645-1653$

Shimada Y, Imamura M, Wagata T, Yamaguchi N, Tobe T (1992) Characterization of 21 newly established esophageal cancer cell lines. Cancer 69: $277-284$

Sneddon P, Westfall TD, Todorov LD, Todorova SM, Westfall DP, Nickel P, Kennedy C (2000) The effect of P2 receptor antagonists and ATPase inhibition on sympathetic purinergic neurotransmission in the guinea-pig isolated vas deferens. Br J Pharmacol 129: 1089-1094

Vandewalle B, Hornez L, Revillion F, Lefebvre J (1994) Effect of extracellular ATP on breast tumor cell growth, implication of intracellular calcium. Cancer Lett 85: 47-54

Vindelov L, Christensen IJ (1990) An integrated set of methods for routine flow cytometric DNA analysis. Methods Cell Biol 33: 127-137

Weidema AF, Dixon SJ, Sims SM (2001) Activation of P2Y but not P2X(4) nucleotide receptors causes elevation of $\left[\mathrm{Ca}^{2+}\right]_{\mathrm{i}}$ in mammalian osteoclasts. Am J Physiol Cell Physiol 280: C1531-C1539

Yamamoto K, Korenaga R, Kamiya A, Qi Z, Sokabe M, Ando J (2000) P2X(4) receptors mediate ATP-induced calcium influx in human vascular endothelial cells. Am J Physiol Heart Circ Physiol 279: H285-H292

Yamane N, Makino M, Kaibara N (1999) S-phase accumulation precedes apoptosis induced by preoperative treatment with 5 -fluorouracil in human colorectal carcinoma cells. Cancer 85: 309-317

Zoeteweij JP, van de Water B, de Bont HJ, Mulder GJ, Nagelkerke JF (1993) Calcium-induced cytotoxicity in hepatocytes after exposure to extracellular ATP is dependent on inorganic phosphate. Effects on mitochondrial calcium. J Biol Chem 268: 3384-3388 